\title{
An ever-changing place: interpreting landscape change in Sagarmatha National Park, Nepal; re-photographic survey and encounter
}

\author{
Rodney Garrard, Thomas Kohler, Urs Wiesmann, Martin F. Price, Alton C. Byers \& Ang Rita Sherpa
}

Keywords: repeat photography, socio-economic change, land-cover change, landscape dynamics, UNESCO World Heritage Site, protected mountain areas

\section{Abstract}

Repeat photography reveals changes in Sagarmatha (Mt. Everest) National Park and Buffer Zone - a microcosm of the Himalayas. The principal author re-took historical photographs from the same viewpoints, illustrating cultural landscape change and persistence over 50 years. The photographs were then used as a basis for interviews with local people.

The research also shed light on socio-economic change, particularly in land cover. It proved that repeat photography can rapidly provide important insights into landscape change patterns, cause, and management options.

\section{Profile}

Protected area

Sagarmatha National Park

Mountain range

Himalayas

Country

Nepal

\section{Introduction}

Human interaction with landscapes creates cultural landscapes (Antrop 2005; Naveh 2000) that contain much information, both ecological and social (Nassauer 1995; Nüsser 2001). As humans impact on almost every place on Earth, mountains included (Messerli et al. 2000), the world is a patchwork of cultural landscapes.

The use of repeat photography to study cultural landscape change in the Khumbu region (or SNPBZ Sagarmatha National Park and Buffer Zone) is part of an ongoing $\mathrm{PhD}$ study (Figure 1).

What would repeat photography highlight about the changes in SNPBZ over 50 years? Can the method clarify landscape / land-use changes (Webb et al. 2010) and cope with the temporal and spatial complexity of environmental \& landscape change (Moss 2000)?

The research revealed the variety and complexity of change in SNPBZ, particularly in land cover. It also revealed Sherpas' views on change. This deserves consideration as an application of repeat photography. Thus, this article first reviews recent contributions to the methodology, and pros and cons, then draws broader conclusions on landscape change in SNPBZ.

\section{Repeat photography}

Repeat photography monitors landscape change via two or more images taken in the same spot over time (Webb et al. 2010). The method can document change over three timescales: years, decades and / or centuries; seasons (e.g. vegetation - Nüsser 2000); or one-off events such as landslides (Ives 1987). Time-lapse photography takes the latter to the extreme (Trimble 2008).

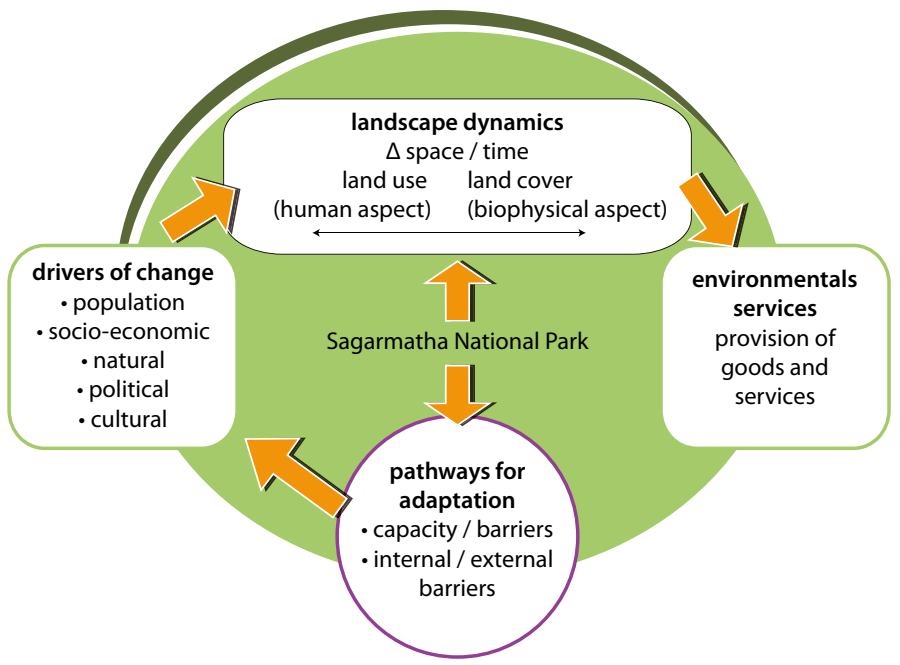

Figure 1 - Relationships between the different elements in the broader PhD project.

Repeat photography studies cover topics as diverse as geomorphology (Cerney 2010), biogeography and forest ecology (Turner et al. 2010; Veblen 2010), glacial recession (Zängl \& Hamberger 2004; Byers 2007), range management (Lewis 2010; Western 2010), and historical architecture (Moore 2010) but over 90\% focus on ecological or physical landscape change (Webb et al. 2010). The use of repeat photography in human geography is relatively new (Kull 2005; Nüsser 2001).

Compared to aerial photography and satellite imaging, it is less comprehensive and more biased. But it costs less, particularly if done during other fieldwork, is not limited by air space restrictions, cloud cover or complex topography and is easily recognizable by lay viewers. It can increase temporal depth (Webb et al. 2010) by adding data older than aerial or satellite images. 
Conservation polices: natural protected area designation and strong restrictions on timber use, agriculture.

Diversification of economic activities emergence of a tourism economy.

Differential territorial development.

Govt. programmes regulating trade and establishing a cash economy. Intensification of agriculture.

Differential appropriation of natural resources and territory.

The arrival of the first international trekking tourists.
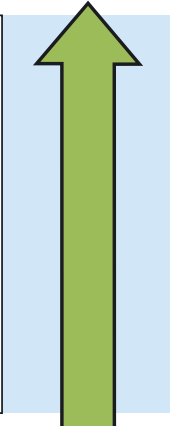

2011 - Golden jubilee of Khumjung School. Nepal Year of Tourism. Visitors to

SNPBZ $=34571+$

2002 - Significant decline in tourism due to Maoist conflict (13 786).

1994 - Austria funded 600-kilowatt hydorelectric scheme near Thame.

1996 - End of domestic monopoly of air service to Lukla - numerous private carriers expanded service to Lukla, greatly facilitating the numbers of tourists.

1990 - SNP created local forest management committees - giving Khumbu officials more authority of administering forest use.

1990 - The panchayat village government system replaced by village development committees (VDCs).

1979 - SNP began tightly regulating forest use by locals and visitors. SNP declared a UNESCO World Heritage Site.

1976 - The Khumbu region gazetted as SNP, Sagarmatha being the official Nepali governmental name bestowed upon Mt Everest.

1974 - First lodge built for tourism in Namche (284 lodges in 2012).

1973 - The number of trekking tourists grew from 300 to 3000 in 3 years.

1972 - Nepal national park system established, modeled on the US Yellowstone model.

1964 - The airstrip at Lukla was built to aid the building of the schools in the region.

1960 - Nepal's King introduces the panchayat land system, ending centuries of political autonomy in the Khumbu.

1959 - Chinese places strong trade restricitons on the border trade.

1953 - First successful ascent of Mt Everest.

1951 - The overthrow of Nepal's Rana rulers who had kept Nepal almost secluded from the outside world for 100 years.

1828 - Nepal government awarded the Sherpas a monopoly in trading rights north \& south of the Khumbu.

1814-16 - Nepal closed its borders for the next 133 years, further isolating the remote Khumbu region.

ca. 1615 - Tibetan Buddhist institutions formally establish in the Khumbu.

ca. 1533 - Ancestors arrive in the Khumbu.

cross-border trading / migration system.

Figure 2 - Historical timeline related to landscape change in the Khumbu (adapted from Stevens 1993). SNPBZ - Sagarmatha National Park and Buffer Zone. SNP - Sagarmatha National Park.

\section{Understanding landscape change}

One pair of repeat photographs may be too specific; comparing across sets of photographic pairs helps minimize problems of scale and bias (Webb et al. 2010). In SNPBZ, this outlined different patterns of change, especially in vegetation, which generally increased for various reasons (see also Byers 2005), including declining pastoralism and village growth via tourism profits (Nepal et al. 2002), which can be seen in the photographs.

Sometimes the more significant changes at a site were economic and commercial, particularly in villages on the main trail to Everest. Figure 3 shows that traditional civic centres (monasteries gombas or chortens) have either grown or been supplanted by commercial lodges.

Tensions of change often evoke nostalgia: "When I look at these photographs, we have lost so much, everything has changed ... everything has a price in today's life, even stone and sand." Everyone smiled at the older photographs. Many said they preferred the way it used to be, but that in general things are better now.

The fieldwork illuminated local perceptions of environmental change and sometimes the disjuncture between perception and reality. This helps inform the photographic observations and understanding of land use history (Figure 2).

\section{Field encounters inform the re-photographic survey}

Chance encounters with prominent Sherpas illustrate another cultural aspect of repeat photography. For example, at a bird sanctuary high above Khumjung village (Figure 5), Tenzing Tashi Sherpa greeted me and we briefly discussed the area. He told us the forest had once supplied firewood and building mate- 

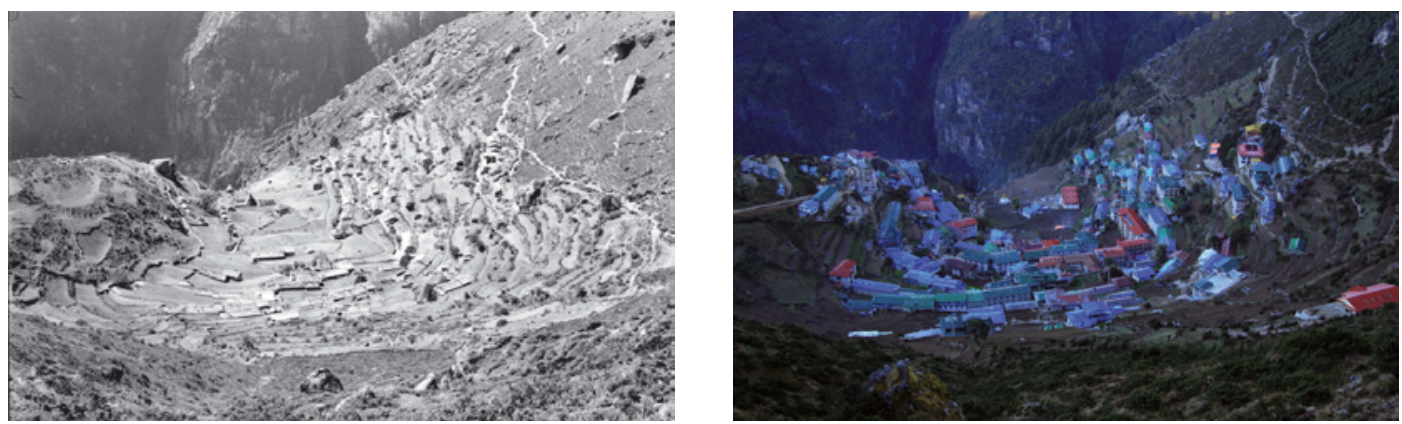

Figure 3 - Namche Bazar in 1955 and 2010. Today Namche has grown significantly and is the administrative centre and headquarters for SNPBZ authorities. Namche's monastery (gompa), centre right, with yellow roof and surrounding sacred grove (Lu), has grown in size. (C) left: F. Müller (1956), courtesy of G. Kappenberger's \& A.Byer's archives; right: R. Garrard (2010).
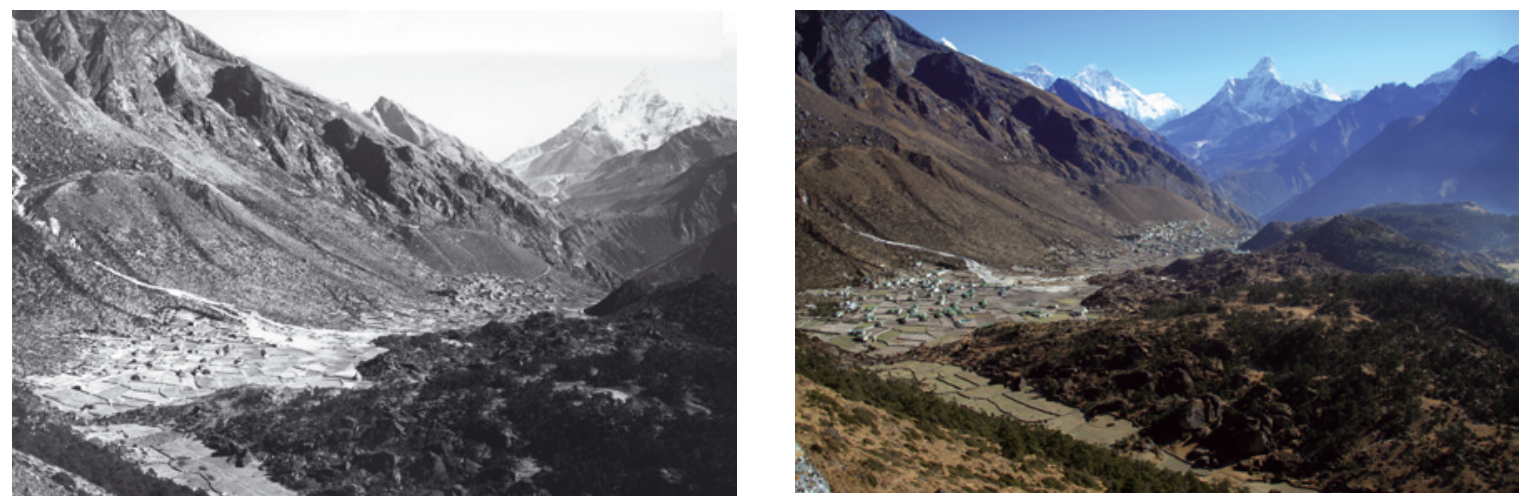

Figure 4 - The villages of Kunde and Khumjung in 1961 and 2009. Both villages have increased in size by more than 50\% between 1961 and 1995 (Byers 2005), an increase largely attributed to population growth (Stevens 2003). These growth trends appear to be continuing as of 2011 (Ang Rita Sherpa pers. comm.). There has been an increase in trees in the forest, centre right, which is a mixture of protected (Kyakshing) and sacred forest groves (Lami nati). The area of vegetation on the slope behind both villages and the left slope behind the village of Kunde (Gyajo Valley) has increased perhaps two- to threefold, probably due to an increase in vegetation and new plantings (Tenzing Tashi Sherpa pers. comm. 2011). The U-shaped valley is characterized by sandy, nutrient poor, former lake and alluvial terraces. (C) left: E.F. Schneider (1961), courtesy of A. Byers; right: R. Garrard 2009 after A. Byers.
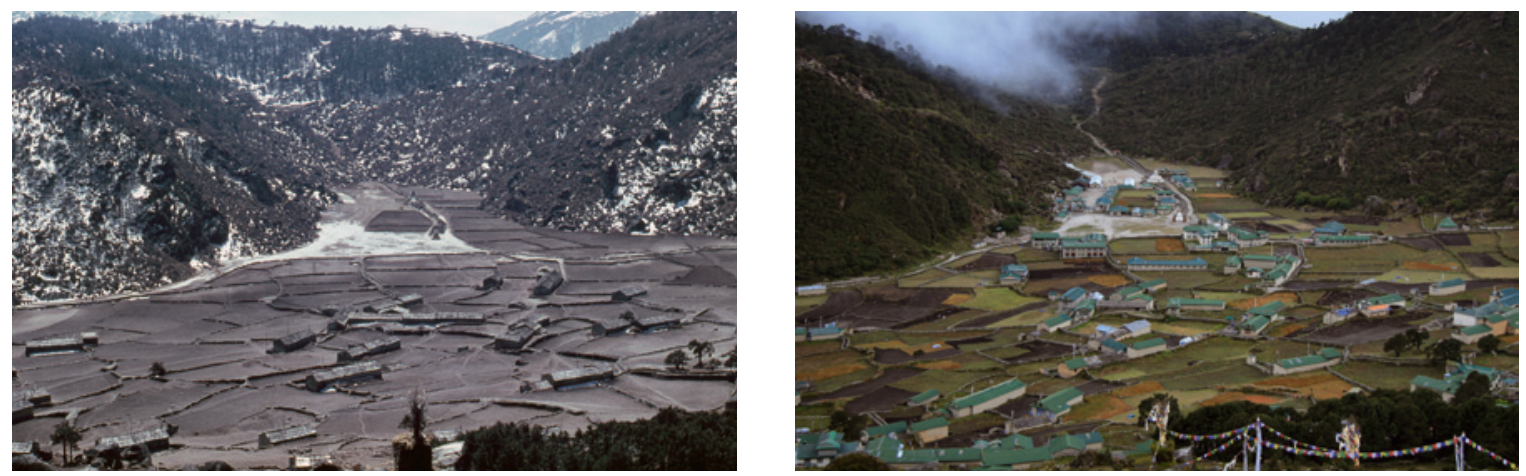

Figure 5 - Khumjung in 1966 and 2011. The photograph was taken en route to the bird sanctuary. The school (Khumjung School) and group of lodges at the village's south entrance (2011) has become the new civic space of the settlement. The settlement's sacred forested grove (Lu) surrounding the monastery is shown. The forested areas are decorated with prayer flags extolling the virtues of trees and forests and the pertinence of planting and caring for them (Tenzing Tashi Sherpa pers. comm. 2011) - a landscape of conservation ideology. Part of the recent complexes of what the author terms dooryard gardens used for intensive potato cultivation are shown. (C) left: H. Heuberger (1966), right: R. Garrard 2011.

rials until the vegetation was destroyed by cattle used for Everest expeditions. "It's beautiful, the forest. We need forest here. It's good ... The relationship between the national park staff and the local people does not help these forests ... the National Park is always looking for Sherpa mistakes ... which has caused more chopping or cutting of trees. We used to have thicker forests around here."
In the village of Dingboche (Figure 6), Sonam Hishi Sherpa said the village had grown much, especially since the 1990s. When he was a child, he said, "it was so different. It was much smaller. I went to Pharak to work in the fields but now they (non-Sherpas) are coming here in our village ... The production methods are fast, giving fast cash ... Nowadays people here live for today." His comments reflect a 

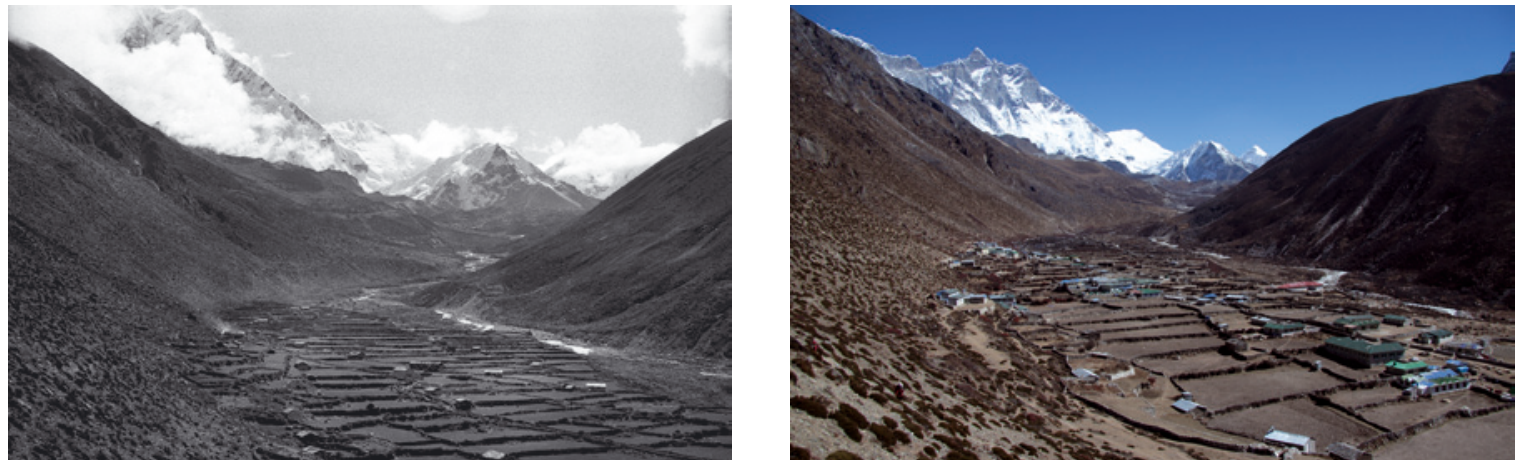

Figure 6 - Dingboche village in 1977 and 2011. The spectacular terracing so ubiquitous in SNPBZ is shown and has historical origins. Note the apparent increase in juniper cover on alpine slopes upstream of Dingboche, most likely related to a locally imposed ban on juniper cutting since 2004. Dingboche was traditionally a summer pasture (gunsa) area but is now inhabited year-round due to tourism development and is one of the remaining villages that impose D-system (communal regulation of livestock system). The village has grown in size since the late 1990s due to trekkers preferring the sunnier side of the upper Imja valley and the popular climb of Imjaste (Island Peak $6032 \mathrm{~m}$ ) centre-right. (C) left: B. Jefferies (1977); right: R. Garrard (2010).
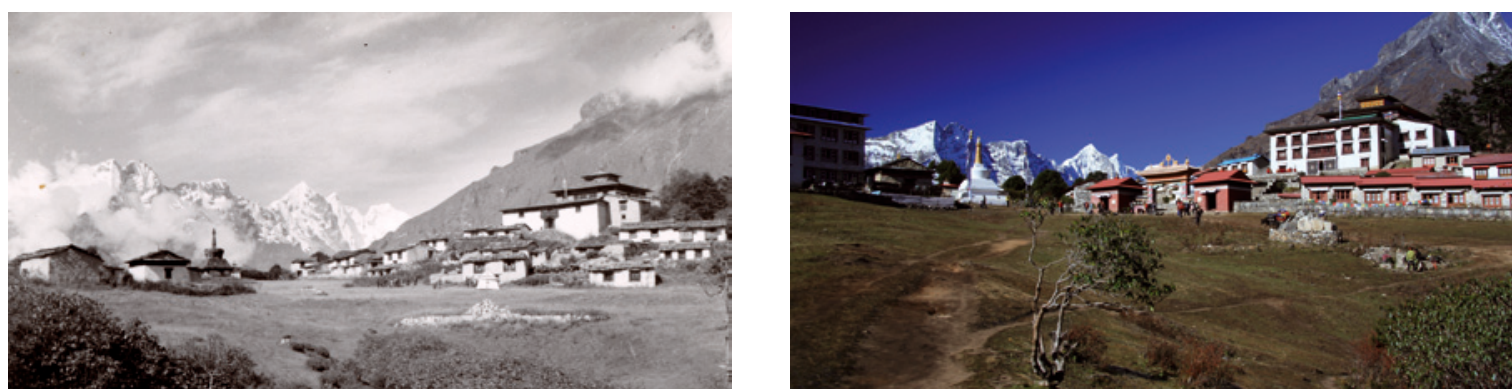

Figure 7 - Tengboche Monastery in 1951 and 2010. The monastery has been the heart of Sherpa culture since 1916. The 1951 photograph was taken on the British Mt. Everest reconnaissance expedition. The monastery was reconstructed in 1989 after a fire, to look similar to the former design from the outside. Surrounding Tengboche are well-established community-protected forests (Kyakshing) and sacred forest groves (Lu). (C) left: The Royal Geographical Society (UK) Everest Collection (1951); right: R. Garrard 2011. Different focal length and vegetation prevented an exact repeat.

sense of mourning for traditional agro-pastoral values, on the one hand, and welcoming earning opportunities on the other.

We said there seemed to be more shrub juniper surrounding the village than in the mid-1970s. He told us that the Khumbu Alpine Conservation Committee (of which he was chair) had banned the use of juniper as firewood in 2004. This is seen as positive.

When asked about changes to buildings, he replied: "All the building materials used to be stone and mixed mud/ clay. All the timber was local fir and juniper - very durable. Now the timber mostly comes from Jiri, Solu or from Kathmandu (plywood) to Synboche via belicopter; the costs are buge ... Some of these building materials last, but others are poorly designed for the conditions in the Khumbu."

At Tengboche Monastery (Figure 7), I had the privilege of speaking with the Tengboche Ringboche (spiritual leader of the Sherpa people). He stressed that Sherpas are at great risk of losing their culture and language: "The schools are responsible for the loss of traditional language as well as clothing, because the school's students only learn modern things there... Because of the media, we know more of other cultures than our own. We never used to celebrate Dashain (National Hindu festival). The pressure from the (Hindu) Government is having an effect on the culture of the local people."

\section{Interpreting change}

In the 1950s and early 1960s SNPBZ was far less developed and could only be reached by foot or on the back of an animal; resource consumption was far more restricted; there was little or no communication technology and no modern education. However, by the mid-1960s, a transition into the tourist era began (Fisher 1990). Ties with Tibet loosened and the valley was integrated into Nepal (Figure 2).

With new income opportunities in mountain expeditions (Brower 1991), new roles replaced animal husbandry: lodge owner, trekking guide, government worker, globe-trotting trader, university lecturer and politician.

At the time of F. Müller's visit (1956), see Figure 3, the population of SNPBZ was estimated to be 2200 Sherpas (today ca. 5750) and almost everyone worked in agriculture, trade and animal husbandry. Despite romantic Western notions, massive engagement in trade (Stevens 1993) suggests the region had hit or exceeded its agricultural limits well before the tourist era.

SNPBZ in 2011 is more connected, modern and economically diverse, with airports, cell phones, radios, TVs and internet access. Boon or blight is one label for the dilemma posed by tourist development in the 
region (Byers 2005; Nepal et al. 2002; Stevens 2003). Not all villages have grown; those that have are located conveniently along the main trails (Brower 1991) and have economically progressive attitudes toward growth and tourism (Byers 2005).

Larger changes in social, political, ethnic and economic spheres, and land use associated with them, are often triggers for environmental change (Head 2004). Understanding the context of change may help explain why it happens.

Economic diversification and growth, increased health care and access, transport, communication, and education mean that many Sherpas no longer farm or cut firewood. Perhaps this leads to increased forest cover? With conservation concerns came the landscaping of settlement forests, adorned with prayer flags announcing their virtue as symbolic forests, landscape manifestations of people's feelings for the environment.

\section{Discussion}

Repeat photography allowed us to see biophysical and cultural changes that reflect a variety of larger forces at work. The fieldwork provided opportunities to interact with Sherpa residents, gaining another layer of understanding.

For example, while we observed consistent increases in vegetation, locals kept claiming that it had decreased. Understanding this mismatch may help address tensions between conflicting uses of the forest and current protected area policies.

Before drawing final conclusions, we must look at the adequacy of the method. The findings of a few encounters in the region may not be representative and focusing on socio-economic change risks underrating non-economic factors. This assessment aspires to be a first step in influencing conservation policies in SNPBZ towards broader participation of local stakeholders. The broader research project (Figure 1) aims to create a critical dialogue around issues important to residents and to catalyze community self-organization.

\section{Conclusion}

Repeat photography offers both specific empirical measures of landscape change and a more holistic perspective combining interviews and oral history. It can also give a contextual perspective on specific changes, on how and why people see them. This insightful method will hopefully continue to develop and help us understand some of the many complex factors at play in our landscape change assessments in protected mountain areas.

\section{References}

Adger, W.N., I. Lorenzoni \& K.L. O’Brien (eds.) 2009. Adapting to Climate Change. Thresholds, Values, Governance.

Antrop, M. 2000. Background concepts for integrated landscape analysis. Agriculture, Ecosystems and Environment 77: 17-28.

Antrop, M. \& V. Van Eetvelde 2000. Holistic aspects of suburban landscapes: visual image interpretation and landscape metrics. Landscape and Urban Planning. 50: 43-58.

Antrop, M. 2005. Why landscapes of the past are important for the future. Landscape and Urban Planning. 70: 21-34.

Brower, B. 1991. The Sherpa of Khumbu: People, Livestock and Landscape. Delhi.

Byers, A.C. 1987. An assessment of landscape change in the Khumbu region of Nepal using repeat photography. Mountain Research and Development 7 (1): 77-81.

Byers, A.C. 1997. Landscape change in the Sagarmatha (Mt Everest) National Park, Khumbu, Nepal. Himalayan Research Bulletin XVII: 31-41.

Byers, A.C. 2000. Contemporary Landscape Change in the Huascarán National Park and Buffer Zone, Cordillera Blanca, Peru. Mountain Research and Development 20 (1): 52-63.

Byers, A.C. 2005.Contemporary Human Impacts on the Alpine Ecosystems in Sagarmatha (Mt Everest) National Park, Khumbu, Nepal. Annals of the Association of American Geographers 95 (1): 112-140.

Byers, A.C.2007. Anassessment of contemporaryglacier fluctuations in Nepal's Khumbu Himal using repeat photography. Himalayan Journal of Sciences 4 (6): 21-26.

Cerney, L.D. 2010. The Use of Repeat Photography in Contemporary Geomorphic Studies: An Evolving Approach to Understanding Landscape Change. Geography Compass 4 (9): 1339-1357.

Coeterier, J.F. 1996. Dominant attributes in the perception and evaluation of the Dutch landscape. Landscape and Urban Planning 34: 27-44.

Cosgrove, D. 1998. Cultural landscapes. In: Unwin, T. (ed.), A European Geography. London.

Fisher, J. 1990. Sherpas: reflections on change in Himalayan Nepal. Berkeley.

Hay, R. 1998. Sense of place in development context. Journal of Environmental Psychology 18: 5-29.

Head, L. 2004. Landscape and culture. In: Mathews, J.A. \& T.D. Herbert (eds.), Unifying Geography. Common Heritage, Shared Future. London. 240-255.

Ives, J.D. 1987. Repeat photography in debris flow and agricultural terraces in the middle mountains of Nepal. Mountain Research and Development 7 (1): 82-86.

Ives, J.D. \& B. Messerli. 1989. The Himalayan dilemma. London.

Küster, H. 2004. Past landscape use as an ecological influence on the actual environment. In: Palang et al. (eds.), European rural landscapes: persistence and change in a globalising environment. Dordrecht. 445-454. 
Kruger, L. 2005. Community and landscape change in southeast Alaska. Landscape and Urban Planning, 72: 235-249.

Kull, C.A. 2005. Historical landscape repeat photography as a tool for land use change research. NorskGeografiskTidsskrift. Norwegian Journal of Geography 59: 253-268.

Lewis, D. 2010. Cattle, Repeat Photography, and Changing Vegetation in the Victoria River District, Northern Territory, Australia. In: Webb, H.R., E.D. Boyer \& M.R. Turner (eds.), Repeat photography: methods and applications in the natural sciences. Washington DC. 197-210.

Lowenthal, D. 1996. Possessed by the past. New York.

Messerli, B. et al. 2000. From nature-dominated to human-dominated environmental changes. Quarter Science Review 19: 459-479.

Moss, M. 2000. Interdisciplinarity, landscape ecology and the transformation of agricultural landscapes. Landscape Ecology 15: 303-311.

Moore, R.P. 2010. Photography and Rephotography in the Cairngorms, Scotland, UK. In: Webb, H.R., E.D. Boyer \& M.R. Turner (eds.), Repeat photography: methods and applications in the natural sciences. Washington DC. $262-274$

Nassauer, J.I. 1995. Culture and changing landscape structure. Landscape Ecology 10: 229-237.

Naveh, Z. 2000. What is holistic landscape ecology? A conceptual introduction. Landscape and Urban Planning 50: 7-26.

Norton, W. 1989. Explorations in the understanding of landscape: A cultural geography. New York.

Nüsser, M. 2000. Change and persistence: contemporary landscape transformation in the Nanga Parbat region, northern Pakistan. Mountain Research and Development 20: 348-355.

Nüsser, M. 2001. Understanding cultural landscape transformation: a re-photographic survey in Chitral Eastern Hindukush, Pakistan. Landscape and Urban Planning 57: 241-255.

Pickard, J. 2002. Assessing vegetation change over a century using repeat photography. Australian Journal of Botany 50 (4): 409-411.

Raitz, K. 2001. Field observation, archives, and explanation. Geographical review 91: 121-131.

Rowntree, L. 1996. The cultural landscape in American geography. In: Earle, C. et al. (eds.), Concepts in human geography. 127-160.

Schild, A. 2008. ICIMOD's Position on Climate Change in Mountain Systems. The Case of the Hindu Kush-Himalayas. Mountain Research and Development 28: 328-331.

Smadja, J. 2009. [1st edition 2003]. Reading Himalayan Landscapes over time. Environmental Perception, Knowledge, and Practise in Nepal and Ladakh. Paris.

Stevens, S.F. 1999. Claiming the High Ground: Sherpas, Subsistence, and Environmental Change in the Highest Himalaya. Berkeley and Los Angeles.
Stevens, S.F. 2003. Tourism and deforestation in the Mt Everest region of Nepal. The Geographical Journal 169 (3): 255-277.

Trimble, S.W. 2008. The use of historical data and artefacts in geomorphology. Progress in Physical Geography 32 (1): 3-29.

Turner, M.R. \& S.H. Bullock 2010. Plant Population Fluxes in the Sonoran Desert Shown by Repeat Photography. In: Webb, H.R., E.D. Boyer \& M.R. Turner (eds.), Repeat photography: methods and applications in the natural sciences. Washington DC. 119-132.

Upreti, B.R. 2009. Nepal from war to peace: legacies of the past and hopes for the future. New Delhi.

Veblen, T.T. 2010. Disturbance and Vegetation Dynamics in the Southern Andean Region of Chile and Argentina. In: Webb, H.R., E.D. Boyer \& M.R. Turner (eds.), Repeat photography: methods and applications in the natural sciences. Washington DC. 167-185.

Webb H.R., E.D. Boyer \& M.R. Turner (eds.), Repeat photography: methods and applications in the natural sciences. Washington DC.

Zängl, W. \& S. Hamberger 2004. Gletscher im Treibhaus. Tecklenborg Verlag, Stienfurt

\section{Authors}

\section{Rodney Garrard}

is a $\mathrm{PhD}$ candidate at the Centre for Development and Environment (CDE), University of Bern, Switzerland. His dissertation is exploring landscape dynamics in the Everest region, Nepal: www.garrard.co.nz

$\mathrm{He}$ is also a member of the UIAA Mountain Protection Commission; IUCN WCPA Tourism and Protected Areas Group and IUCN's World Commission on Protected Areas (WCPA); email: rodney.garrard@cde.unibe.ch

\section{Thomas Kohler}

is Associate Director at the Centre for Development and Environment (CDE) and lecturer at the Department of Geography of the University of Bern. He works in the mountains of Eastern Africa and the Horn, the Caucasus, Nepal and Switzerland, with a focus on development dynamics, livelihoods and regional development.

\section{Urs Wiesmann}

has a profound background in research on sustainable regional development. He is Professor in Geography at the University of Bern and co-director of the Centre for Development and Environment (CDE) and of the National Centre of Competence in Research (NCCR) North-South.

\section{Martin F. Price}

is Director of the Centre for Mountain Studies at Perth College, University of the Highlands and Islands, UK, where he holds the UNESCO Chair in Sustainable Mountain Development. 
Alton C. Byers

$\mathrm{PhD}$ is a mountain geographer, climber, and photographer specializing in community-based alpine conservation programs, applied research, and climate change impacts in high altitude mountain regions. $\mathrm{He}$ has worked for The Mountain Institute since 1990 and is currently co-manager of the USAID-funded High Mountain Glacial Watershed Program with projects in Nepal, Peru, and Tejikistan.

\section{Ang Rita Sherpa}

is TMI's Senior Program Manager, has more than 20 years of professional experience in the implementation of mountain protected area, ecotourism, community based tourism and sustainable development projects. He graduated from the University of Wales, UK, in 2001 in Protected Area Landscape Management. 